\title{
Diversity of mosses in Mt. Makiling forest reserve, Philippines
}

\author{
AILENE A. ALCALA ${ }^{1,2, \bullet}$ \\ ${ }^{1}$ Plant Biology Division, Institute of Biological Sciences, College of Arts and Sciences, University of the Philippines Los Baños, Laguna, Philippines. \\ Tel.: +63-49-5362807, •email: aaalcala1@up.edu.ph \\ ${ }^{2}$ Graduate School, University of the Philippines Los Baños, Laguna, Philippines
}

Manuscript received: 25 March 2019. Revision accepted: 28 May 2019.

\begin{abstract}
Alcala AA. 2019. Diversity of mosses in Mt. Makiling forest reserve, Philippines. Biodiversitas 20: 1729-1734. One of the essential parts of ecosystem diversity are the mosses. The study aimed to compare the diversity of mosses along altitudinal gradients in the Makiling and Sipit trails of the Mt. Makiling Forest Reserve (MMFR). Sampling plots were established every $100 \mathrm{~m}$. asl elevation. Moss specimens were collected inside a $100 \mathrm{~m}^{2}$ plot and re-examined under dissecting and compound microscope. A total of 77 moss species were identified in all plots established in which 43 and 48 species from Makiling and Sipit trail, respectively. Low species richness in lower elevation can be explained by higher degree of disturbances compared in higher elevation. Furthermore, species richness, diversity and abundance increase with increasing elevation. In contrast, higher temperature decreases species richness, abundance and diversity. In general, moss diversity is positively affected by increasing elevation in both trails. This is also supported by correlation analysis on moss species composition for the two sampling sites while sudden decreases in diversity in sampling plots located at $600 \mathrm{~m}$. asl and $900 \mathrm{~m}$. asl (Sipit Trail) and $800 \mathrm{~m}$. asl and 1,000 m. asl (Makiling Trail) could simply be due to the presence of canopy gaps or disturbances in the site. Results implied that mosses used as indicators for impacts of climate change due to their sensitivity to environmental changes.
\end{abstract}

Keywords: Abundance, bryophyte, Mt. Makiling Forest reserve, species richness, moss diversity

\section{INTRODUCTION}

Bryophyte is a collective term for small, simple, sporebearing, non-vascular plants characterized as having a dominant gametophyte generation and unbranched diploid sporophytes that remain attached to the maternal gametophyte throughout their life span; thus, are characterized to have a heteromorphic life cycle (Shaw and Beer 1999). Under bryophytes, mosses (Bryophyta) is one of the significant components of ecosystem biodiversity and an important part of species diversity (Grytnes et al. 2006; Steel et al. 2004). It also plays an important role in the forest vegetation by giving a good soil structure, soil stability and water retention (Bates 2000). A scientific base has been identified to justify the uses of the bryophytes such as some liverworts and moss extracts have antibacterial, antifungal, antiviral activity, detoxicant and antitumor (Wu 2007). Recently, there have been 150 ethnobotanical species of bryophytes reported to be more interesting both because of their relative rarity, lowly and small growth plants and for the insights they can provide about the relation between people and the medicinal value it can give (Haris 2008).

In the Philippines, the moss checklist of the Philippines (Tan and Iwatsuki 1991) enumerates 700 species, under 228 genera belonging to 55 families, including a number of mosses from Mt. Makiling. In Mindanao Island, a total of 187 genera and 314 species of mosses, 50 of which are known only from this island. The rest are found also in Luzon and the islands of the Visayas. Among the 50 species of Philippine mosses known from Mindanao, 4\% are widespread in the tropics, $60 \%$ are Malesian taxa, $21 \%$ have an Australasian link, 10\% have a Bornean link, and only $6 \%$ have a continental Asiatic connection. Clearly, the moss flora of Mindanao has a strong southern and Australasian influence compared to other large islands in the country (Tan 1998).

In the case of Mt. Makiling, it was reported that the mountain caters 155 species (Tan and Iwatsuki 1991). Botanically, the mountain is extensively studied in terms of vascular flora as exemplified by the works of Pancho (1983), Pancho and Gruezo (2006), Gruezo (2000), Lambio and Buot (2011), Abraham et al. (2010).

Mt. Makiling Forest Reserve (MMFR) is a favorable locality for the study as it is regarded as one of the best known biological areas and one of the 18 centers for plant diversity in the Philippines. In view of this, there is a need to conduct moss bryoflora in MMFR. The study aimed to provide the baseline/update of moss species list in two (2) forest trails of Mt. Makiling and to compare species diversity between Makiling Trail and Sipit Trail.

\section{MATERIALS AND METHODS}

\section{Study area}

Mt. Makiling is located at $13.87 \mathrm{~N} 120.9 \mathrm{E}$ and $14.28 \mathrm{~N}$ 121.5 E (Figure 1). Mt. Makiling Forest Reserve (MMFR), Philippines is subdivided into four sub-watersheds: Molawin-Dampalit, Cambantoc, Tigbi, and the Greater Sipit. The study was conducted in two sites: Greater Sipit and Molawin-Dampalit subwatershed from 300-1000 m. asl. 


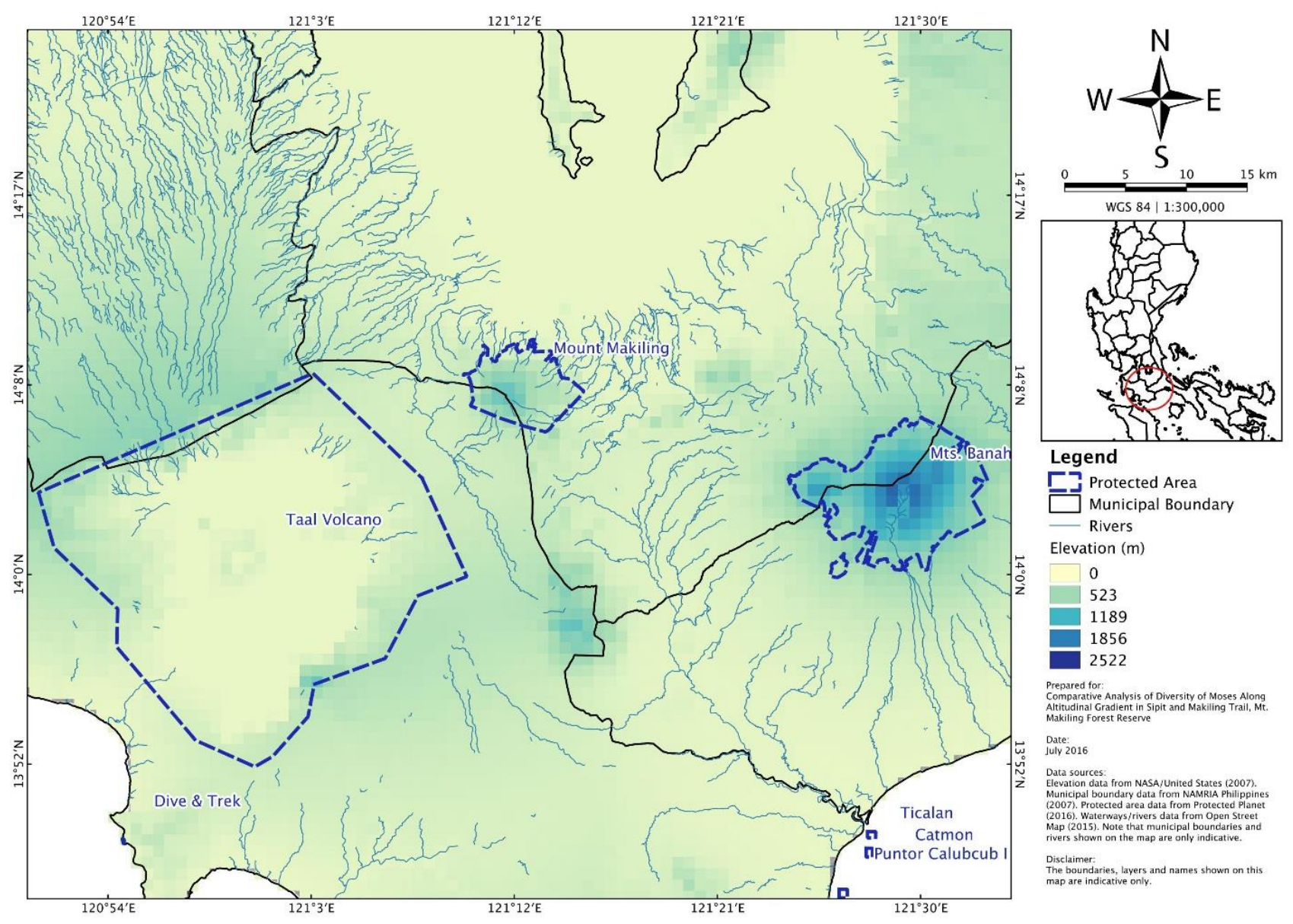

Figure 1. Location map of Mt. Makiling Forest Reserve, Philippines

Table 1. GPS reading of sampling plots in Makiling and Sipit trails Philippines

\begin{tabular}{|c|c|c|c|c|}
\hline \multirow{3}{*}{ Plot no. } & \multicolumn{4}{|c|}{ GPS reading } \\
\hline & \multicolumn{2}{|c|}{ Makiling trail } & \multicolumn{2}{|c|}{ Sipit trail } \\
\hline & Northing & Easting & Northing & Easting \\
\hline 1 (300 m. asl) & 14.141944 & 121.230306 & 14.11126 & 121.18680 \\
\hline 2 (400 m. asl) & 14.136056 & 121.229222 & 14.11744 & 121.18594 \\
\hline 3 (500 m. asl) & 14.129528 & 121.210944 & 14.12008 & 121.18507 \\
\hline $4(600 \mathrm{~m} . \mathrm{asl})$ & 14.13375 & 121.208056 & 14.12076 & 121.18314 \\
\hline $5(700 \mathrm{~m} . \mathrm{asl})$ & 14.138528 & 121.205250 & 14.12289 & 121.18434 \\
\hline $6(800 \mathrm{~m}$. asl $)$ & 14.139222 & 121.199028 & 14.12485 & 121.18464 \\
\hline 7 (900 m. asl) & 14.137917 & 121.196806 & 14.13172 & 121.18451 \\
\hline 8 (1000 m. asl) & 14.136194 & 121.195722 & 14.13309 & 121.18458 \\
\hline
\end{tabular}

Prior to the collection proper, a reconnaissance survey was conducted in the study area along an altitudinal gradient as a confirmatory step to verify the presence of mosses in the area. Using the Global Positioning System (GPS), the elevation and geographical location of the sampling plots were determined (Table 1).

\section{Field methods}

Modified belt transect method was used to survey the moss bryoflora in two (2) forest trails of Mt. Makiling. Altitudinal transect plots using modified belt transect method were laid out in a left to right manner parallel to the existing trail (as transect line). Plots were laid out starting at $300 \mathrm{~m}$. asl to $1,000 \mathrm{~m}$. asl. From the trail, a two-meter length or distance was measured to the left and two meters to the right. Sixteen (16) sampling plots measuring $10 \mathrm{~m} \mathrm{x}$ $10 \mathrm{~m}$ were established where moss samples were collected and studied (Figure 2).

Mosses found in different substrate (ground, rock or tree) were collected within sampling plots. Stand-up technique (after Shevock et al. 2014) was used in processing the voucher specimen. 


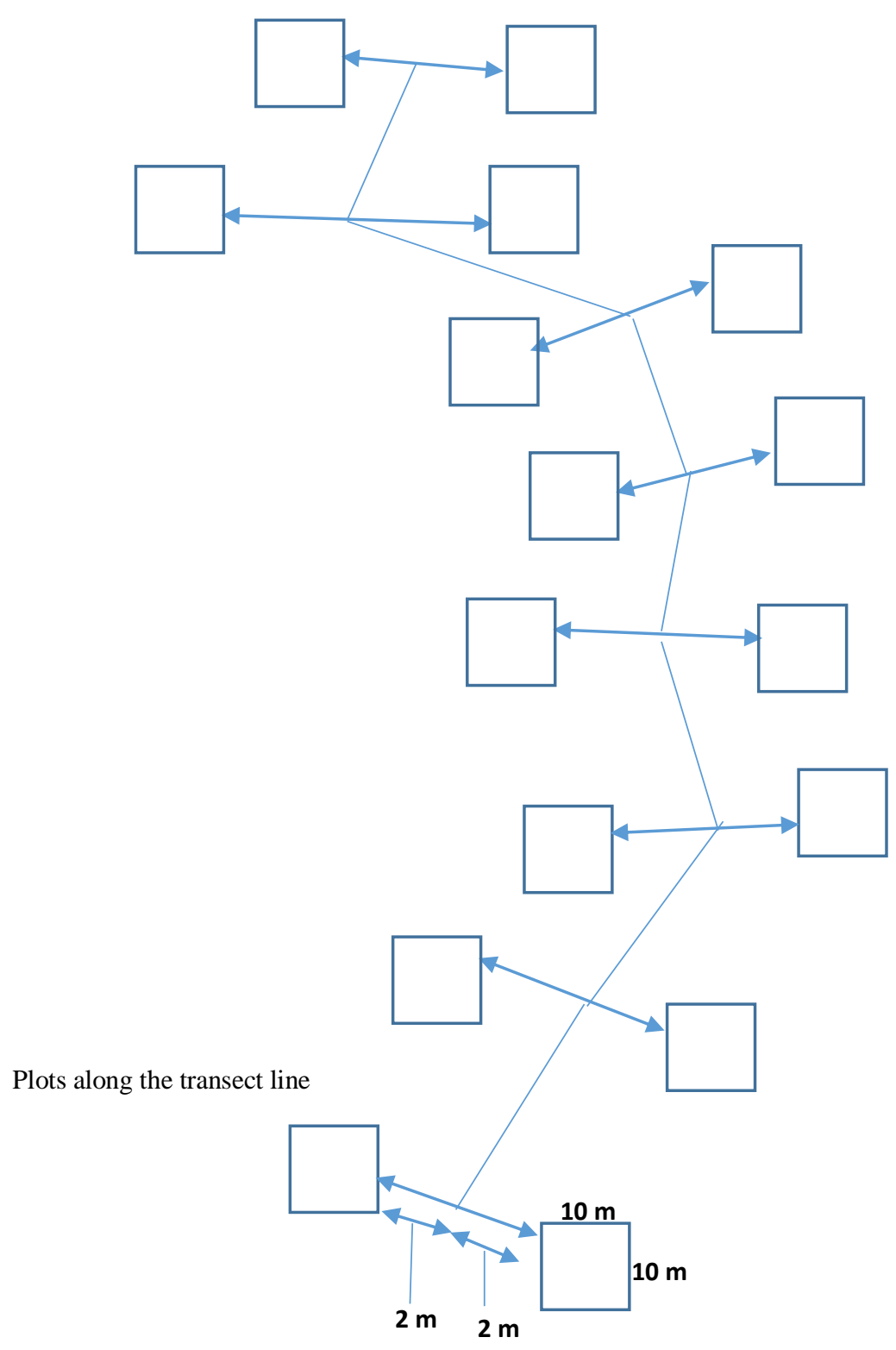

Figure 2. The modified belt transect method

\section{Species identification}

Moss specimen were photo-documented in situ. Specimens were re-examined under a dissecting microscope at the Forest Biological Sciences laboratory, College of Forestry and Natural Resources, University of the Philippines Los Baños (FBS, CFNR, UPLB). The samples were identified following Bartram (1939) and Tan and Iwatsuki (1991) using recent taxonomic treatment for mosses. Bartram's Mosses of the Philippines was used in identifying the specimens. The morphology and diagnostic characters such as characters of the stem, stem leaves, branch leaves, capsule, seta and the calyptra (if present) were used for classification.

\section{Data analysis}

Analysis of species richness and composition between the two trail communities were performed using $\mathrm{R}$ software v. 3.2.1. R (Tippmann 2015).
NMDS ordination technique was used to determine moss compositional pattern between the two trails. Map of plots was constructed in community composition space using a community dissimilarity matrix based from Euclidean distances.

The distribution of moss species along an altitudinal gradient was determined and plotted each species richness, species diversity $\mathrm{H}$ (Shannon diversity), and abundance against elevation. Species turnover analysis was presented to interpret moss flora composition along altitudinal gradient using the $\mathrm{R}$ package and calculates total turnover as well as the proportion of species that either appear or disappear between altitudinal sampling plots in each trail communities. 


\section{RESULTS AND DISCUSSION}

A total of 77 moss species belonging to 17 families with 44 genera were identified in plots established in two altitudinal trail communities in MMFR. This accounts for $50 \%$ of the total moss species in Mt. Makiling and $\sim 11 \%$ of the total moss species listed in the country (Tan and Iwatsuki 1991). Only 14 species (18\%) belonging to 12 families were common to both trail communities. Hypnaceae is the most represented family with 14 species, followed by Calymperaceae ( $9 \mathrm{spp}$.), Sematophyllaceae ( 8 spp.), Fissidentaceae (7 spp.) and Neckeraceae and Leucobryaceae (6 spp.). The five most abundant species were Leucoloma molle (C. Mull.) Mitt. with 15 individuals, followed by Taxithelium instratum (Brid.) Broth (10), Arthrocormus schimperi (Dozy \& Molk.) Dozy \& Molk and Lorentzia bifaria (Bosch \& Lac.) Buck \& Crum (8) and Calymperes subintegrum Broth. (7).

Between the two trails, Sipit Trail has a higher species richness with 48 moss species compared to Makiling trail's 43 species. Seventy-one percent $(71 \%)$ of moss families are common to both trails. These include family Brachytheciaceae, Calymperaceae, Dicranaceae, Fissidentaceae, Hypnaceae, Hypnodendraceae, Leucobryaceae, Meteoriaceae, Neckeraceae, Pterobryaceae, Sematophyllaceae and Thuidiaceae. The remaining $29 \%$ of moss families were characterized as unique to both Sipit and Makiling trails. These are species belonging to families Funariaceae, Hookeriaceae, Pottiaceae, Polytrichaceae and Stereophyllaceae. These show that the moss family composition in the two trails is almost the same.

\section{Species richness comparison between trails}

Makiling trail's moss flora belong to 14 families under 29 genera with Calymperaceae as the most represented family having 6 species (Calymperes subintegrum Broth.; C. subserratum M. Fleisch.; C. tenerum C. Mull.; M. cf flavum, Syrrhopodon aristifolius Mitt. and S. loreus (Lac.) Reese) followed by Fissidentaceae and Neckeraceae with 5 species each (Fissidens crenulatus var. elmeri (Broth.) Iwats. \& Suzuki; F. hollianus Dozy \& Molk.; F. hyalinus Hook. \& Wils.; F. laxus Sull. \& Lesq. and F. zippelianus var. robinsonii (Broth.) Iwats. \& Suzuki; Himantocladium plumula (Nees) Fleisch.; Homaliodendron exiguum (Bosch \& Lach) Fleisch.; H. flabellatum (Sm.) Fleisch.; Pinnatella mariei (Besch.) Broth. and Neckeropsis lepineana (Mont.) Fleisch).

The most dominant species found in Makiling trail are Leucoloma molle (C. Mull.) Mitt., Arthrocormus schimperi (Dozy \& Molk) Dozy \& Molk., Calymperes subintegrum Broth. and Lorentzia bifaria (Bosch \& Lac.) Buck \& Crum. These species belong to family Dicranaceae, Leucobryaceae, Calymperaceae, and Thuidiaceae, respectively. These were anchored to tree barks, trunks, branches, and dead/fallen logs. Majority of the species were thriving on trees $(88.4 \%)$, followed by those on rock and soil substrate with $9.3 \%$ ad $2.3 \%$, respectively. This preference could be due to the availability of water and nutrient in tree trunks which is favorable for vigorous growth of most bryophytes (Goffinet and Shaw 2009).

Leucoloma molle (C. Mull.) Mitt. can be found in higher elevations (1,000, 900, 800 and $700 \mathrm{~m}$. asl) and Arthrocormus schimperi (Dozy \& Molk.) Dozy \& Molk.can be located in 1,000 and $900 \mathrm{~m}$. asl. While Calymperes subintegrum Broth. can be found in 700 and $600 \mathrm{~m}$. asl and Lorentzia bifaria (Bosch \& Lac.) Buck \& Crum can be found in lower elevations (600, 400 and 300 $\mathrm{m}$. asl). Obviously, abundance of mosses was observed in higher elevations than in lower elevations. In this study, abundance increase with increasing altitudes. Relative moisture increases as altitude increases (Myers et al. 2000). Abundance is more likely because of their relative moisture conditions that are suitable habitat for bryophytes.

In Sipit trail, moss flora belongs to 16 families under 32 genera with Hypnaceae as the most represented family having 10 species (Ectropotheciella distichophylla (Hampe) Fleisch, Ectropothecium falciforme (Dozy \& Molk.) Jaeg., E. perminutum Broth ex Bartr., Glossadelphus zollingeri (C. Mull.) Fleisch., Isopterygium pendulum Dix. ex Bartr., Trachythecium micropyxis (Broth.) Bartr., Vesicularia dubyana (C. Mull.) Broth., V. montagnei (Bel.) Broth., V. reticulata (Dozy \& Molk.) Broth. and Taxiphyllum taxirameum (Mitt.) Fleisch.), followed by Calymperaceae with 6 species(Calymperes erosum C. Mull., C. graeffeanum C. Mull., C. subintegrum Broth., C. tahitense (Sull.) Mitt., C. tenerum C. Mull. and Syrrhopodon aristifolius Mitt.) and Leucobryaceae and Sematophyllaceae with 5 species each (Arthrocormus schimperi (Dozy \& Molk.) Dozy \& Molk., Leucobryum scalare C. Mull. ex Fleisch., L. neilgherrense Mull. Hal., Leucophanes candidum (Schwaegr.) Lindb., and $L$. octoblepharioides Brid.) and Acanthorrynchium papillatum (Harv.) Fleisch., Acroporium sigmatodontium (C. Mull.) Fleisch., Taxithelium gottscheanum (Hampe ex C. Mull.), Taxithelium instratum (Brid.) Broth. and Taxithelium nepalense (Schwaegr.) Broth.

The most dominant species found in Sipit trail are Taxithelium instratum (Brid.) Broth., Stereophyllum anceps (Bosch \& Lac.) Broth. and Ectropotheciella distichophylla (Hampe) Fleisch. These species belong to family Sematophyllaceae, Stereophyllaceae and Hypnacea, respectively. These are mostly grown on trees (bark, branch, base, trunk), rock, and soil substrate. Sipit trail is a forested, slightly rolling, rocky and undisturbed area with favorable moisture condition or environment and good for the growth of mosses. Majority of the species were thriving on trees $(58 \%)$, followed by those of rock and soil substrate with $33.3 \%$ and $8.3 \%$, respectively. Similar with data on Makiling trail, the highest number of moss species were located on trees due to its moisture content, water and nutrients found on this substrate (Goffinet and Shaw 2009).

Family Hypnaceae can be found in both high and low elevations and this is same with family Calymperaceae, Leucobryaceae and Sematophyllaceae. These families are distributed in low and high elevations because of wind dispersal of spores. It might be blown by the wind from a higher to lower place. This was explained in the study of 
Johansson et al. (2015), that higher proportion of the spores reached high altitudes through wind speed.

Seventy-one percent $(71 \%)$ of family of moss are common to both Sipit and Makiling trails. These include family Brachytheciaceae, Calymperaceae, Dicranaceae, Fissidentaceae, Hypnaceae, Hypnodendraceae, Leucobryaceae, Meteoriaceae, Neckeraceae, Pterobryaceae, Sematophyllaceae and Thuidiaceae. The remaining $29 \%$ of family of moss were characterized as unique to both Sipit and Makiling trails. These are species belonging to families Funariaceae, Hookeriaceae, Pottiaceae, Polytrichaceae and Stereophyllaceae. Collectively, almost three-fourths (3/4) of the moss family are normally found in both trails while more than onefourth (1/4) of the moss family are exclusively found in both trails. These data emphasized that the family composition in Sipit trail is almost the same as the families found in Makiling trail. It is proven that MMFR is an untouched area and rich moss flora diversity.

All elevations of Sipit and Makiling trail have unique species of mosses. Elevation 900 and $1000 \mathrm{~m}$. asl have more unique species with 18 species each, followed by 17 species at $700 \mathrm{~m}$. asl. The least unique species were found in $300 \mathrm{~m}$. asl. This result may indicate that the elevation has significant factor for outcome of uniqueness of species of moss. This was positively the same with the results obtained by some authors regarding high elevation with more unique species compared to lower elevation (Geffert et al. 2013).

\section{Moss species turn over along elevation}

In Sipit trail, the highest species turnover was found in $1000 \mathrm{~m}$. asl with 16 species and the lowest species turnover was found in $600 \mathrm{~m}$. asl elevation (2 species). On the other hand, the highest species turnover in Makiling trail was observed in $900 \mathrm{~m}$. asl with 11 species and lowest species turnover was found in $300 \mathrm{~m}$. asl with only 3 species (Figure 3).
As noted, the species turnover showed variable fluctuations in the species composition in Makiling and Sipit trail. Species turnover gives the proportion of species that either appears or disappear between altitudinal points. In Sipit trail, plots at 500 and $600 \mathrm{~m}$. asl have no species in common, while plots sampled at 300 and $400 \mathrm{~m}$. asl have more species in common. Elevation of $1000 \mathrm{~m}$. asl is the most undisturbed among elevations in Sipit trail. In Makiling trail, high species turnover was observed every altitudinal plot, with plot sampled at 900 to $1000 \mathrm{~m}$. asl having the most species common.

Furthermore, plots located in high elevation showed higher moss abundance. These were also explained by the works of Gradstein and Pocs (1989) which explain this abundance as a result of more favorable moisture conditions due to clouds and fog and the prevailing lower temperatures. The same results were also found by Gonzales-Mancebo and Hernandez- Garcia (1996) in their research on the life strategies of mosses in the Canary Islands.

Generally, the lower diversity and abundance of mosses in lower elevation could be explained by the presence of anthropogenic and natural disturbances as well as the occurrence of open or unforested patches compared with the more conserved and forested areas at higher elevations.

\section{Moss flora species richness and composition analysis}

The result from non-metric multidimensional scale (NMDS) ordination plot showed little divergence between trail communities (Figure 4). In this figure, gray lines indicate paired-site altitudinal plots. Black text in each NMDS plots indicates plot names (GSS = Greater Sipit Subwatershed; MKL = Makiling). Black circles indicate groupings of high and low elevation plots. Communities that have very similar species composition appeared as points near each other whereas communities that have very different species compositions will further away from each other on the ordination plot.

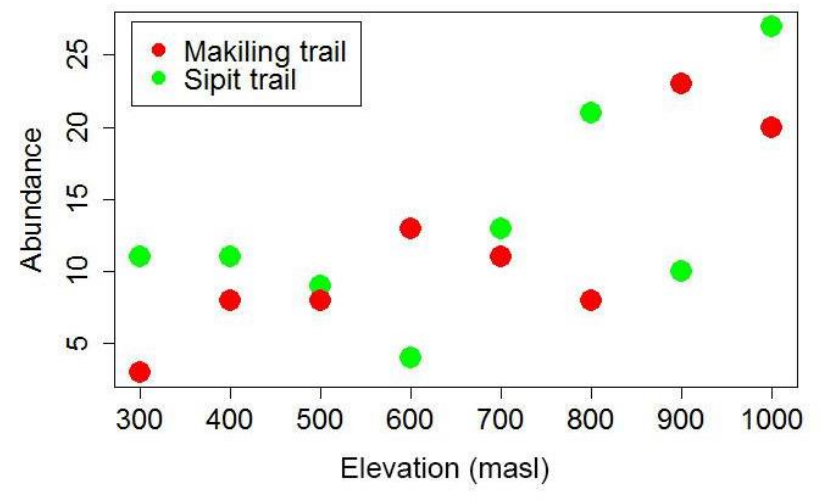

$\mathbf{A}$

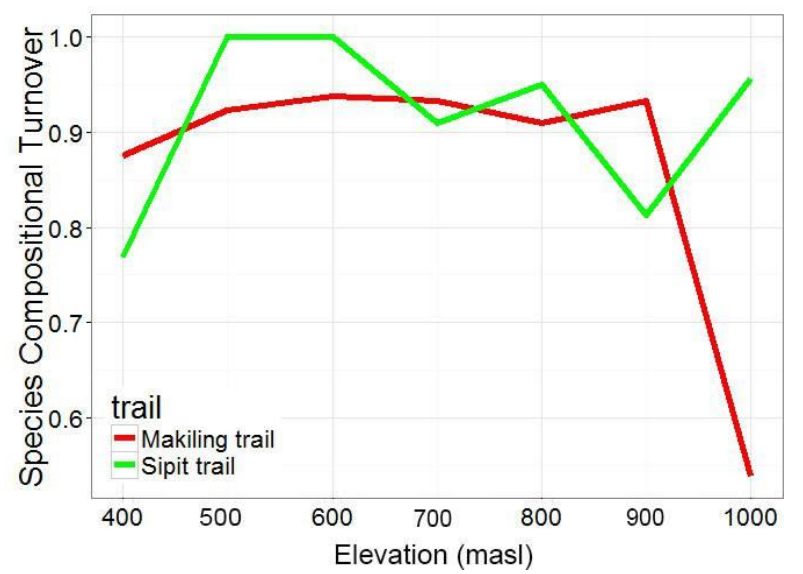

B

Figure 3. Altitudinal structure of moss species in MMFR using (A) species abundance and (B) composition 


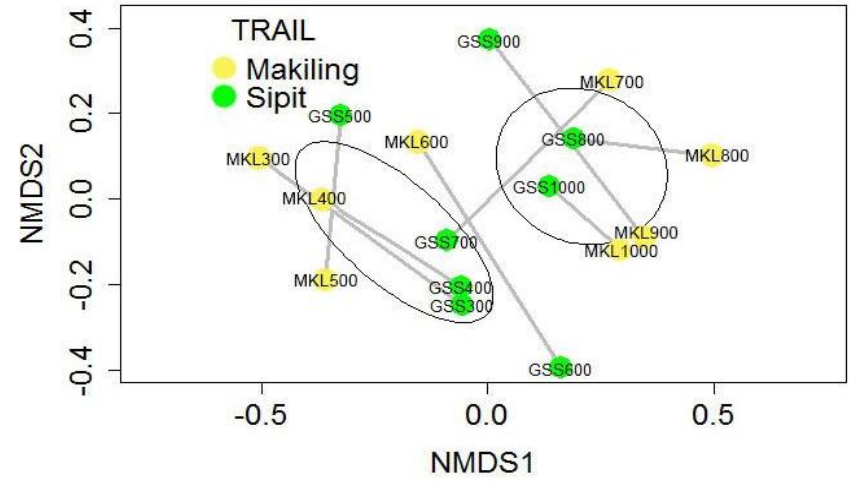

Figure 4. Non-metric multidimensional scale (NMDS) ordination of community composition relative to species abundance in Makiling trail (yellow plots) and Sipit trail (green plots).

Reading in NMDS plots is quite straightforward such that plots constructed in the ordination map that are closer to one another, are likely to be more similar than those further apart. In this result, altitudinal plots with relatively similar communities were plots at 1000 and $900 \mathrm{~m}$. asl in Makiling trail, and plots 300 and $400 \mathrm{~m}$. asl in Sipit trail. NMDS plots in the ordination map showed more affinity to altitudinal (elevation) position of the plots rather than trail community differences, as shown by plot groupings between higher and lower elevation plots, with exception to plot sampled at $700 \mathrm{~m}$. asl in Sipit trail grouping along with lower elevation plots (Figure 4). Also, species composition at altitudinal paired plots is not similar given the long distance (gray line) between paired plots (Figure 4). The result indicates that compositional pattern in MMFR might be related to the present forest types along altitudinal gradient rather than aspect.

\section{Recommendation}

Data collection for moss species richness, diversity, and composition was conducted over a single season (dry season); therefore, it is recommended that a study covering an expanded sampling period (both wet and dry seasons) be conducted. Mosses are particularly sensitive to anthropogenic disturbance. Low moss diversity (richness, diversity $\mathrm{H}$, and abundance) was observed in lower elevation plots which can be related to proximity to human activities. Therefore, forest along low elevation should be addressed for protection and conservation in MMFR, since moss has a significant role in the ecosystem. Furthermore, it is recommended that the moss diversity and composition of the Northeast and Southeast portions of MMFR be compared to this study. Moreover, these could be compared to other similar forest reserves in the Philippines having the same altitudinal gradients.

\section{ACKNOWLEDGEMENTS}

The author would like to express her gratitude to the Makiling Center for Mountain Ecosystems, UPLB for granting access and permit to conduct the research in MMFR and to the Department of Science and Technology (DOST) which provided funds for this study through the Accelerated Science and Technology Human Resources Development Program-National Science Consortium (ASTHRDP-NSC) scholarship.

\section{REFERENCES}

Abraham ERG, Gonzalez JCT, Castillo ML, Lit IL, Jr., Fernando ES. 2010. Forest cover and biodiversity profile of the crater area of Mount Makiling, Luzon, Philippines. Asia Life Sci Suppl 4: 49-82.

Bartram EB. 1939. Mosses of the Philippines. Philippine J Sci 68: 1-437.

Bates JW. 2000. Mineral nutrition, substratum ecology and pollution. Bryophyte Biology. Cambridge University Press, London.

Geffert JL, Frahm JP, Barthlott W, Mutke J. 2013. Global moss diversity: spatial and taxonomic patterns of species richness. J Bryol 35: 1, 111.

Goffinet B, Shaw AJ. 2009. Bryophyte Biology. 2nd ed. Cambridge University Press, New York.

Gonzales-Mancebo JM, Hernandez-Garcia CD. 1996. Bryophyte life strategies along an altitudinal gradient in El Canal y Los Tiles (La Palma, Canary Islands). J Bryol 19: 243-255.

Gradstein SR, Pocs T. 1989. Bryophytes. In: Lieth H, Werger MJA (eds). Tropical rain forest ecosystems. Elsevier Science Publishers b.v., Amsterdam.

Gruezo WS. 2000. Floral diversity profile of Mt. Makiling Forest reserve, Luzon, Philippines. ASEAN Regional Conference on Biodiversity Conservation, 20-21 September 2000, College of Forestry and Natural Resources, U.P. at Los Baños, College, Laguna, Philippines.

Grytnes JA, Heegaard E, Ihlen PG. 2006. Species richness of vascular plants, bryophytes and lichens along an altitudinal gradient in western Norway. Acta Oecol 29: 241-246.

Haris ESJ. 2008. Ethnobryology: Traditional uses and folk classification of bryophytes. Bryologist 3 (2): 169-217.

Johansson V, Lönnell N, Rannik U, Sundberg S, Hylander K. 2015. Air humidity thresholds trigger active moss spore release to extend dispersal in space and time. Dryad Digital Repository. DOI: 10.5061 /dryad.mv346.

Lambio IA, Buot Jr. IE. 2011. Floristic Composition of Woody Species Along the Altitudinal Gradient on Mt. Makiling. Institute of Biological Sciences, University of the Philippines Los Baños, College, Laguna Philippines. Asia Life Sci 20 (2): 369-383.

Myers N, Mittermeier RA, Mittermeier CG, Da Fonseca GAB, Kent J. 2000. Biodiversity hotspots for conservation priorities. Nature 403: 853-858.

Pancho JV. 1983. Vascular flora of Mount Makiling and Vicinity (Luzon: Philippines), Part 1. New Mercury Printing Press, Quezon City.

Pancho JV, Gruezo WSM. 2006. Vascular flora of Mount Makiling and Vicinity (Luzon: Philippines), Part 2. National Academy of Science and Technology, and the Institute of Biological Sciences, College of Arts and Sciences, University of the Philippines Los Banos, Manila

Shaw AJ, Beer SC. 1999. Life history variation in gametophyte populations of the moss Ceratodon purpureus (Deptrichaceae). Am J Bot 86 (4): 512-521.

Steel JB, Wilson JB, Anderson BJ, Lodge RHL, Tangney RS. 2004. Are bryophyte communities different from higher-plant communities? Abundance relations. Oikos 104: 479-486.

Tan BC, Iwatsuki Z. 1991. A new annotated Philippine moss checklist. Harvard Papers Bot. 3: 1-64.

Tan BC. 1998. Noteworthy disjunctive patterns of Malesian mosses. In: Hall R, Holloway JD (eds.). Biogeography and Geological Evolution of SE Asia. Backhuys, Leiden.

Wu PC. 2007. The Medicinal Uses of Bryophytes. Acta Botanica Yunnanica. Kunming Institute of Botany, Academia Sinica, China.

Tippman S. 2015. Programming tools: Adventure with R. Nature 517: 109-110. 